US Army Corps

of Engineers $S_{\overparen{B}}$

Engineer Research and

Development Center

Integrated Climate Assessment for Army Enterprise Planning

\title{
Frequency of Extreme Weather Events Model User's Guide
}

Byron M. Garton

July 2019

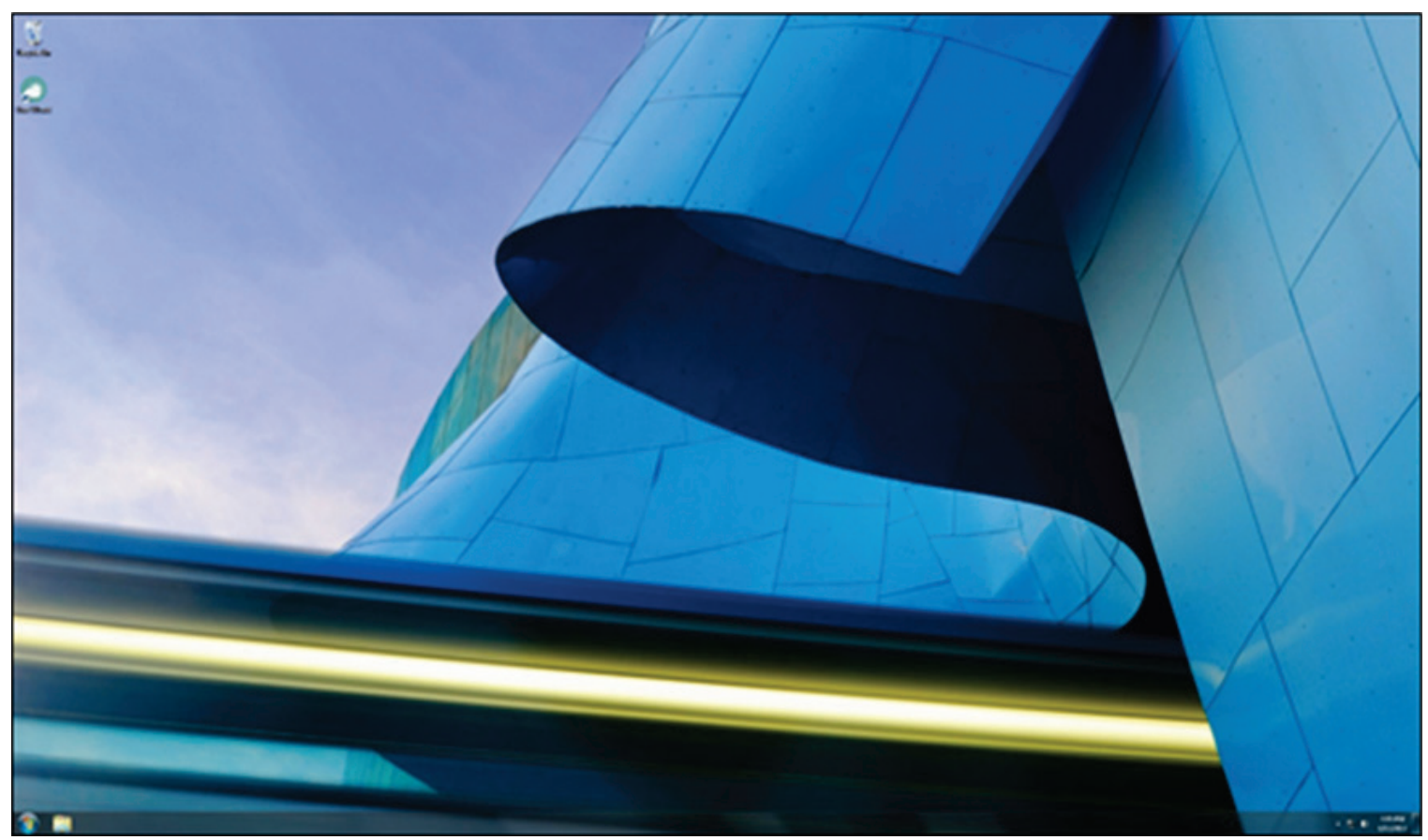


The U.S. Army Engineer Research and Development Center (ERDC) solves the nation's toughest engineering and environmental challenges. ERDC develops innovative solutions in civil and military engineering, geospatial sciences, water resources, and environmental sciences for the Army, the Department of Defense, civilian agencies, and our nation's public good. Find out more at www.erdc.usace.army.mil.

To search for other technical reports published by ERDC, visit the ERDC online library at http://acwc.sdp.sirsi.net/client/default. 


\title{
Frequency of Extreme Weather Events Model User's Guide
}

\author{
Byron M. Garton \\ Information Technology Laboratory \\ U.S. Army Engineer Research and Development Center \\ 3909 Halls Ferry Road \\ Vicksburg, MS 39180-6199
}

Final report

Approved for public release; distribution is unlimited. [or a restricted statement]

Prepared for Headquarters, U.S. Army Corps of Engineers

Washington, DC 20314-1000

Under Project 402188 Integrated Climate Assessment for Army Enterprise Planning 


\section{Abstract}

Extreme weather events such as droughts and extended periods of high temperatures can have a negative impact on future force readiness and effectiveness. This model attempts to predict the likelihood of extreme weather events by calculating probabilities for several scenarios from future climate projections for various Department of Defense (DoD) installations.

This document describes the process of executing the Frequency of Extreme Weather Events Model, as it exists at the time of this writing, within the common computational environment established under the software integration effort of the Integrated Climate Assessment for Army Enterprise Planning work package.

DISCLAIMER: The contents of this report are not to be used for advertising, publication, or promotional purposes. Citation of trade names does not constitute an official endorsement or approval of the use of such commercial products. All product names and trademarks cited are the property of their respective owners. The findings of this report are not to be construed as an official Department of the Army position unless so designated by other authorized documents. 


\section{Contents}

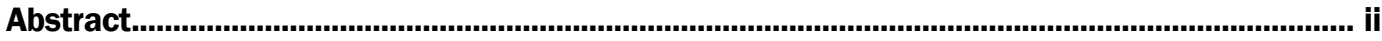

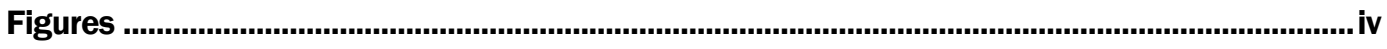

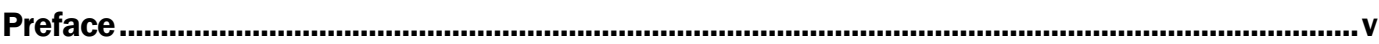

1 Introduction.......................................................................................................................... 1

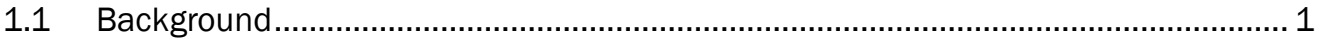

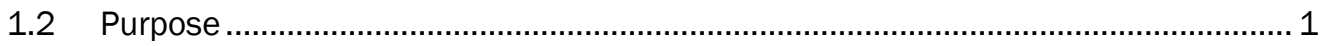

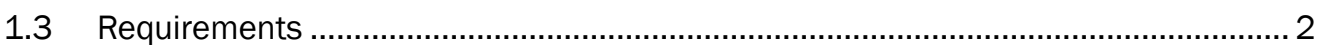

2 Viewing Computed Data .............................................................................................................. 3

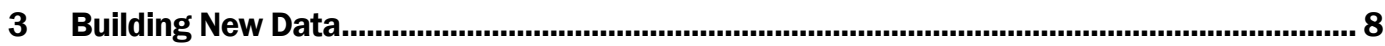

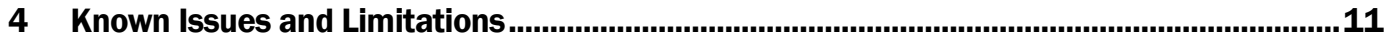

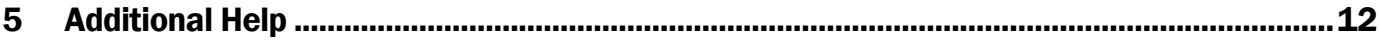

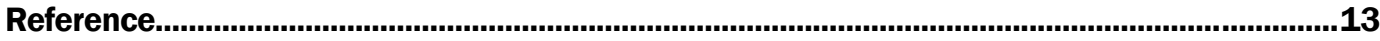

Appendix A: Acronyms and Abbreviations ................................................................................14

Report Documentation Page 


\section{Figures}

\section{Figures}

Figure 1. Wizard application shortcut. ...................................................................................... 3

Figure 2. Frequency of Extreme Events Model icon........................................................................... 4

Figure 3. Frequency of Extreme Events Model first screen................................................................ 4

Figure 4. Frequency of Extreme Events Model second screen......................................................... 5

Figure 5. Results in the chart viewer window. ............................................................................ 6

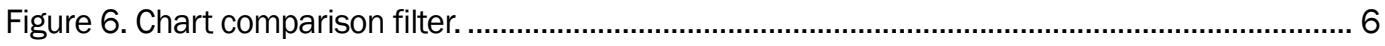

Figure 7. Launch Python IDLE from the third model screen within the Wizard. ................................. 8

Figure 8. Python IDLE development environment...................................................................... 9

Figure 9. Data Fixer tool...................................................................................................... 10 


\section{Preface}

This research was conducted for the U.S. Engineer Research and Development Center-Construction Engineering Research Laboratory (ERDC-CERL) under Project 402188, Integrated Climate Assessment for Army Enterprise Planning. The Technical Monitor was Dr. James D. Westervelt of ERDC-CERL.

The work was performed by the Information Technology Laboratory (ITL), Scientific Software Branch (SSB), of the Computational Science and Engineering Division (CSED). At the time of publication, Mr. Timothy W. Dunaway was Chief of the SSB, Dr. Jerrell R. Ballard was Chief of the CSED, and Mr. Robert M. Wallace was the Technical Director. The Deputy Director of ERDC-ITL was Ms. Patti S. Duett, and the Director was Dr. David A. Horner.

COL Ivan P. Beckman was the Commander of ERDC, and Dr. David W. Pittman was the Director. 


\section{Introduction}

\subsection{Background}

The Frequency of Extreme Weather Events Model attempts to predict the effects of climate change on the frequency of extreme weather. The event scenarios that are currently calculated by the model are:

- Number of days with a temperature greater than $95^{\circ} \mathrm{F}$

- Number of days with a temperature greater than $100^{\circ} \mathrm{F}$

- Number of instances with a temperature greater than $100^{\circ} \mathrm{F}$ for three consecutive days

- Number of days with a temperature less than $10^{\circ} \mathrm{F}$

- Number of days with measured precipitation greater than two inches

- Number of days with measured precipitation less than .01 inches.

Extreme weather events such as droughts and extended periods of high temperatures can have a negative impact on future force readiness and effectiveness. The predicted event frequencies are intended to be utilized in other force stationing analysis applications as a Military Value Analysis (MVA) attribute.

\subsection{Purpose}

This model makes use of a common computational environment and a user assistance application that were implemented as part of the software integration effort within the Integrated Climate Assessment for Army Enterprise Planning work package. The virtual environment will be referred to throughout this document as the Virtual Machine or VM, and the user assistance application will be referred to as the Wizard. For more information about the software integration effort, the virtual environment, and the user assistance application, refer to the Analytical Model Integration Methods Technical Report (2017).

Executing the model is a two-step process that requires using Python IDLE development environment, MS Excel ${ }^{\circledR}$, and a basic text editor such as MS Notepad ${ }^{\circledR}$. Each step for viewing and building data sets is thoroughly documented in the following sections to limit user confusion and ensure accurate results. 


\subsection{Requirements}

Software requirements for the Frequency of Extreme Weather Events Model include the Python IDLE development environment, a basic text editor such as MS Notepad ${ }^{\circledR}$, and MS Excel ${ }^{\circledR}$ version 2013 or higher.

A working knowledge of Microsoft Office products is recommended as well as a basic understanding of editing file paths in a text file and executing Python code within the IDLE environment. 


\section{Viewing Computed Data}

Pre-built dataset viewing is available to end users by accessing the model from within the Wizard application. The Wizard is accessible from the Integrated Climate Assessment for Army Enterprise Planning VM by clicking the shortcut located on the desktop (Figures 1-3).

Figure 1. Wizard application shortcut.

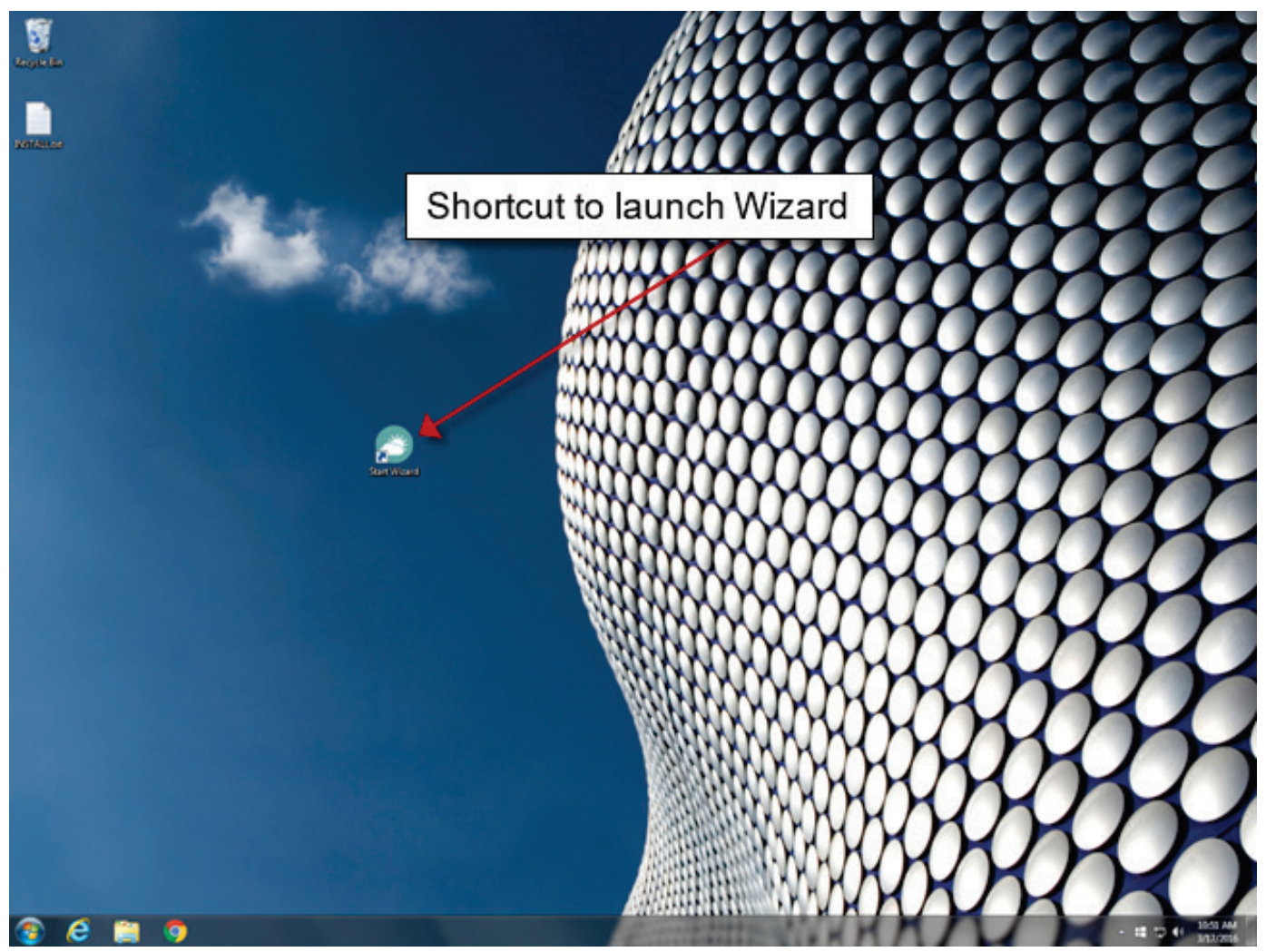


Figure 2. Frequency of Extreme Events Model icon.

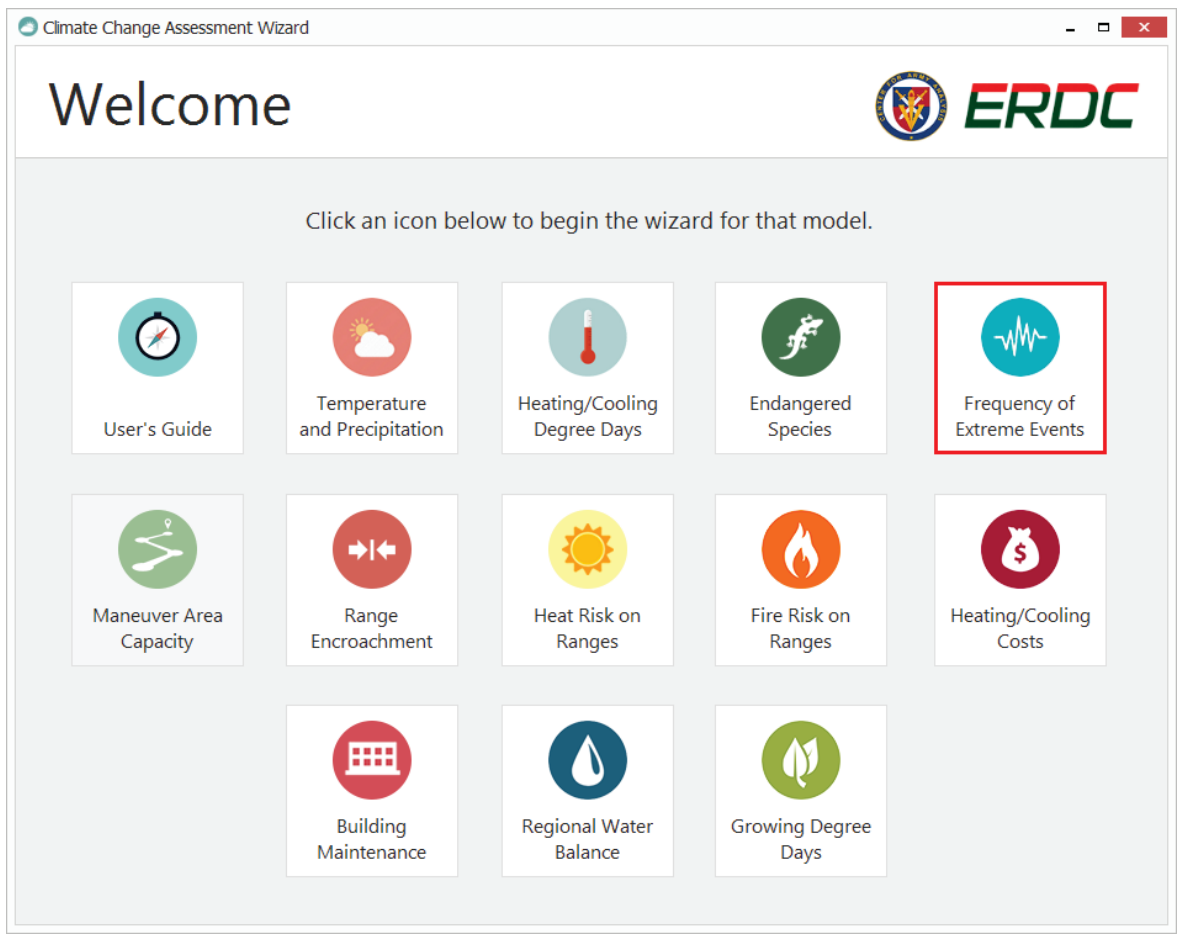

Figure 3. Frequency of Extreme Events Model first screen.

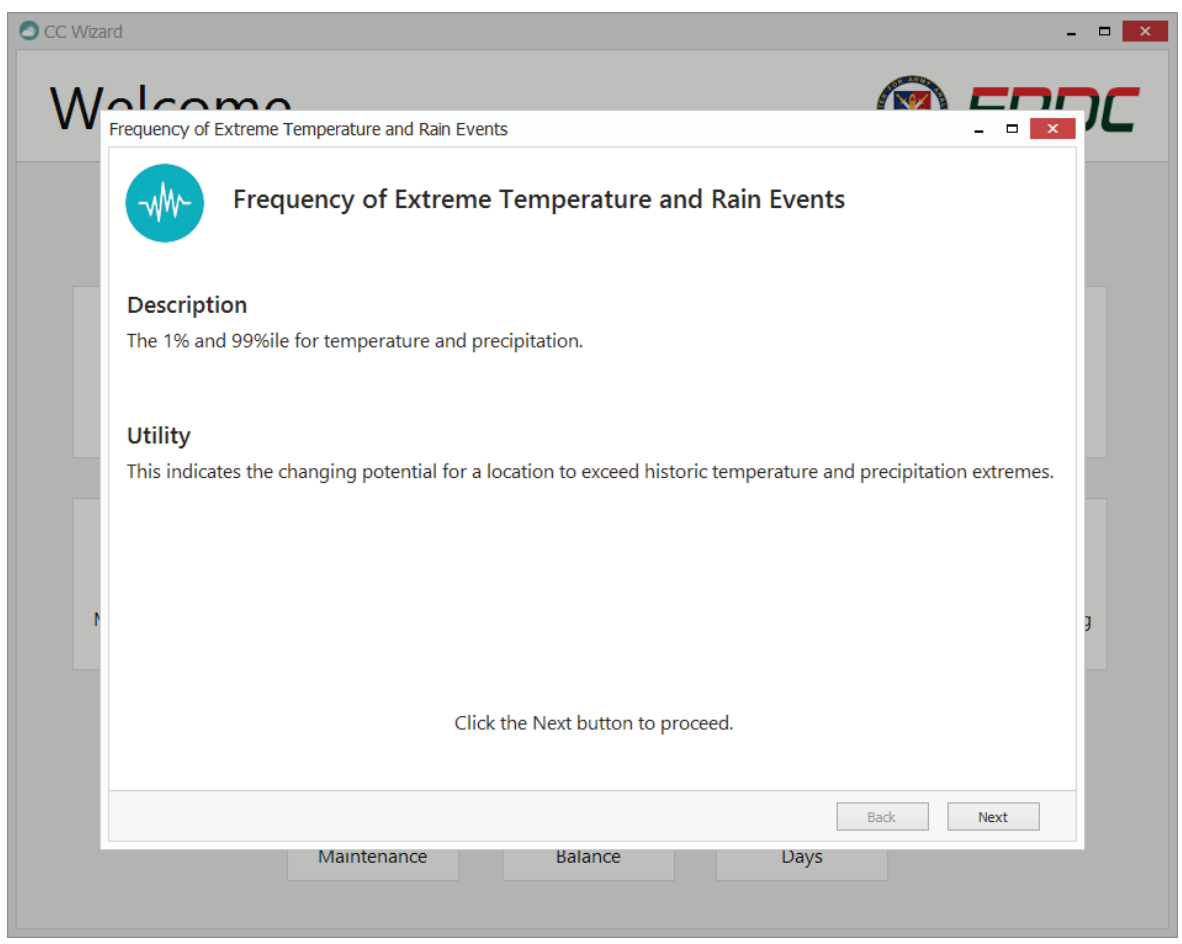

The second screen within the model (Figure 4) allows the end user to view the datasets in graphical or tabular mode. Users can choose the desired view type from the View drop down combo box. Options within this box are 
Graphs and Tabular. Graphs displays the data as standard line graphs while Tabular displays the data in a table layout within an MS Excel ${ }^{\circledR}$ spreadsheet.

Figure 4. Frequency of Extreme Events Model second screen.

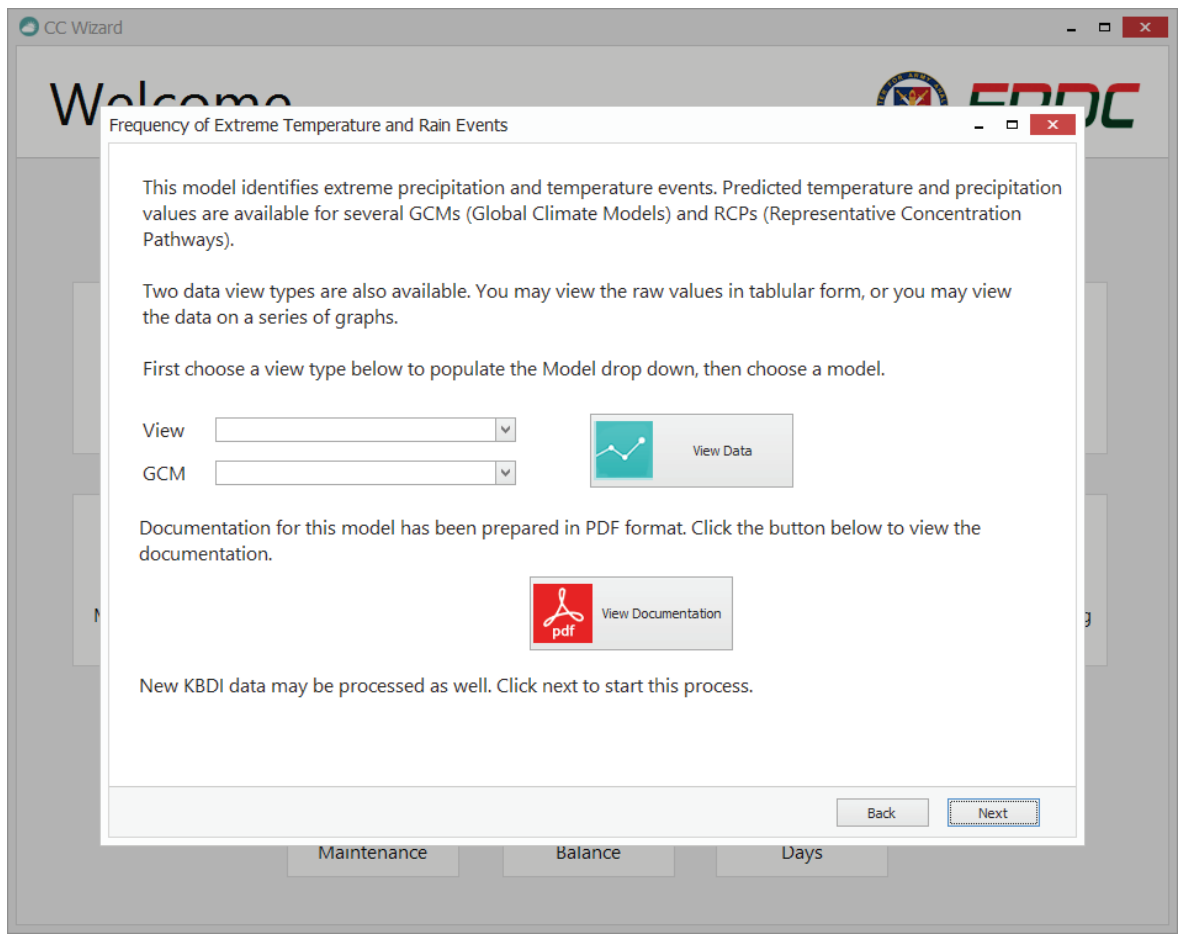

Next, choose a General Circulation Model (GCM) and Representative Concentration Pathway (RCP) type from the drop down combo box to filter only data related to that GCM/RCP. At the time of publication, there are $10 \mathrm{GCMs}$ within the dataset for this model. RCP 2.6, 4.5, and 8.5 were chosen to represent the lower, middle, and upper bounds for each GCM. Each GCM contains these RCPs, with the exception of CNRM-CM-5 and GFDL-CM3.

Once both of the choices are made, click the View Data button to launch the chart viewer window (Figure 5). 
Figure 5. Results in the chart viewer window.

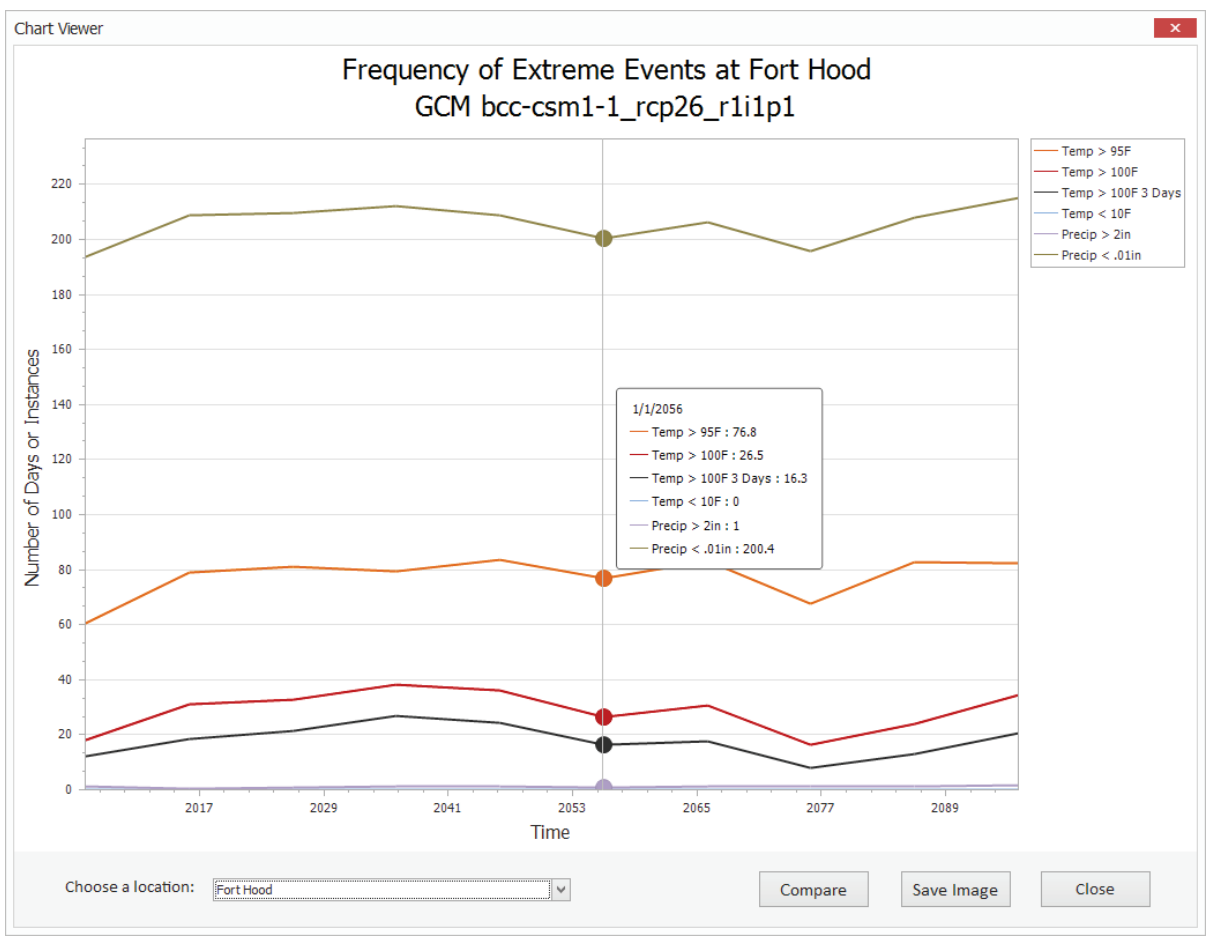

The average number of days or instances in six different event categories are plotted as line graphs with the number of days or instances charted on the $\mathrm{Y}$-axis, and 10-year epochs charted on the $\mathrm{X}$-axis. The user can change the charted values by choosing a different geographical location from the drop down combo box near the bottom left of the window. Upon selecting a location, the data will automatically filter to include only those values found within the chosen area.

Users may also limit the variables that are charted. Clicking the Compare button near the bottom right of the window brings up a dialog where variables may be shown or hidden from the chart (Figure 6).

Figure 6. Chart comparison filter.

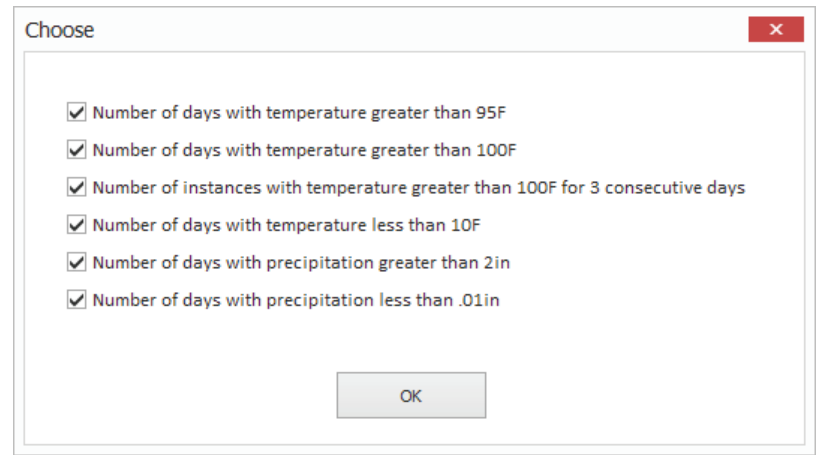


Charts may be saved to the user's computer by clicking the Save Image button near the bottom right of the window (Figure 6). The resulting file is saved to a location of the user's choosing in the universal JPEG image file format. 


\section{Building New Data}

Building new datasets is accomplished within the VM by running a Python Script from the Python IDLE development environment. The following instructions should be followed carefully to produce new data from this model.

The Python IDLE development environment is pre-installed inside the VM and may be launched automatically from the Wizard application or accessed from the Windows Start menu (Figure 7 and Figure 8).

Figure 7. Launch Python IDLE from the third model screen within the Wizard.

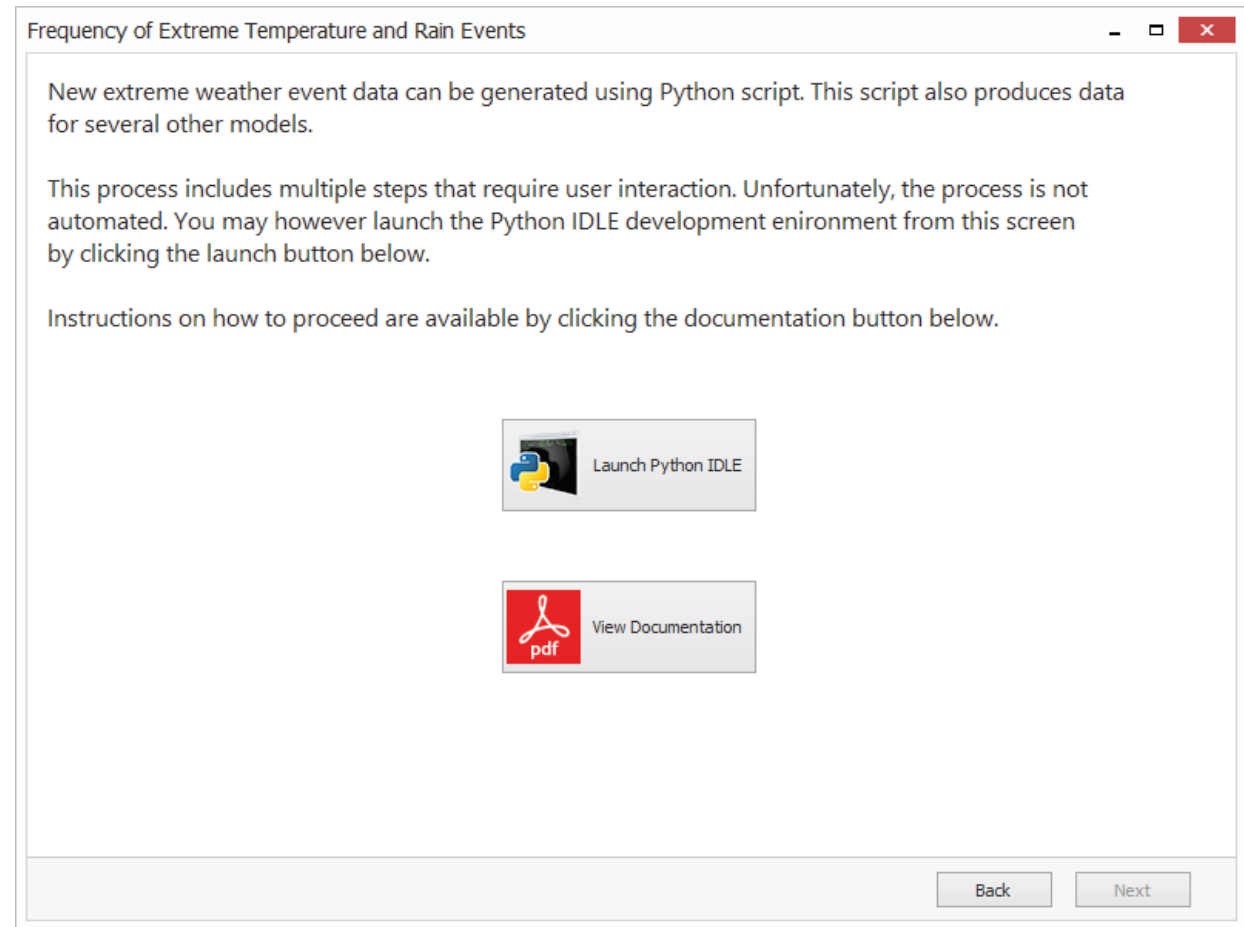


Figure 8. Python IDLE development environment.

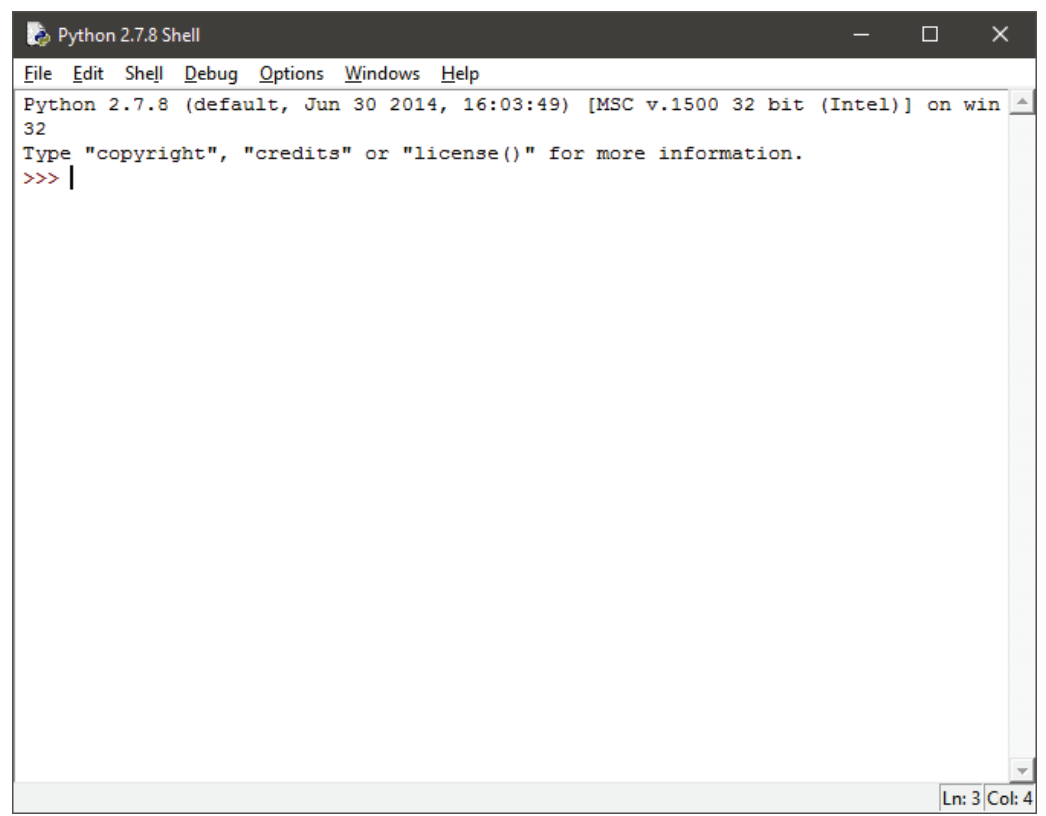

After opening IDLE, open the Python script by selecting File->Open and browse to the file C: \Models \Shared-Data \Model \heatfire risk days climate projections.py. Once the file is loaded, please ensure line 19 points to a text file that contains a list of GCM's to process. This file has been pre-made, so no adjustments to it should be necessary, unless new GCMs are to be processed. The file location is $C: \backslash$ Models $\backslash$ Data-2 $\backslash$ GCM Model Runs.txt. Use a text editor, such as MS Notepad ${ }^{\circledR}$, to make modifications to this file. Also note that daily climate data from the Temperature and Precipitation Model must be processed prior to running this Frequency of Extreme Weather Events Model. Refer to lines 16-18 for the file paths. If new climate data is to be processed, the files that are output from the Temperature and Precipitation Model must be located in the same prior directory, or lines 16-18 must be modified to match the location of the output files. Refer to the user's guide for that model for more information about output files.

Output from this model is in the form of CSV files, one for each GCM/RCP combination. Note that this process can be rather lengthy, depending on the number of GCMs that are being processed. It is not unusual for the script to run for several hours.

After running the Python script, another post processing script must be run (Figure 9). Locate the EXE file in the model folder within the VM. (C: \Models \Shared-Data \DataFixer.exe). Set the input and 
output paths by clicking the Change button. Ensure that the output folder that's entered exists before starting the process. Finally, click Fix It to process the data.

Figure 9. Data Fixer tool.

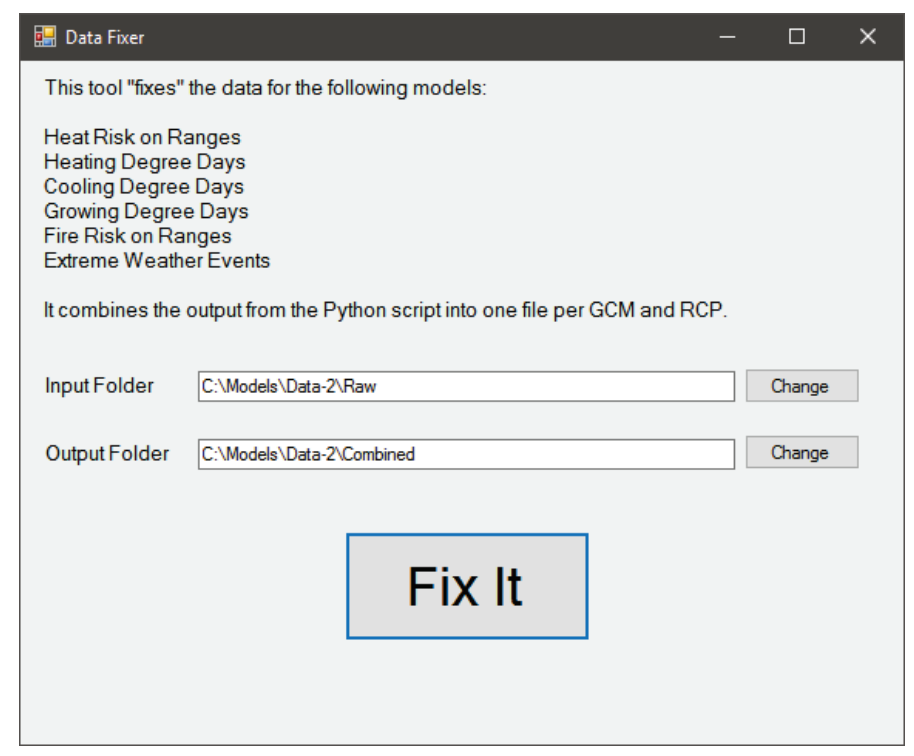

Post processing the data is fairly quick. It should not take more than a couple of minutes to complete. After this step, the data is ready to be viewed within the Wizard application. The post processing application source code is located at $\mathrm{C}: \backslash$ Models $\backslash \mathrm{VS}$

Projects $\backslash$ DataFixerHeatFire. 


\section{Known Issues and Limitations}

Building new data with this model can be a very lengthy process.

Depending on the number of GCMs being processed, it is not unusual for the Python script to take several hours complete, even on very powerful, modern computers. 


\section{Additional Help}

Additional questions or concerns should be directed to the Program Manager of the Integrated Climate Assessment for Army Enterprise Planning program.

Paul M. Loechl

ERDC-CERL

Paul.M.Loech|@usace.army.mil

217-373-5892

Marty Garton

ERDC-ITL

Byron.m.garton@usace.army.mil

601-634-2888 


\section{Reference}

Garton, B. M. 2019. Analytical Model Software Integration Methods. ERDC/ITL SR-194. Vicksburg, MS: Information Technology Laboratory (ITL) - U.S. Engineer Research and Development Center. 


\section{Appendix A: Acronyms and Abbreviations}

\begin{tabular}{ll} 
Term & Definition \\
CSED & Computational Science and Engineering Division \\
CSV & Comma Separated Values \\
DoD & Department of Defense \\
ERDC & Engineer Research and Development Center \\
ERDC-CERL & Engineer Research and Development Center- \\
& Construction Engineering Research Laboratory \\
ERDC-ITL & Engineer Research and Development Center- \\
& Information Technology Laboratory \\
GCM & Global Circulation Model \\
MVA & Military Value Analysis \\
NSN & National Supply Number \\
OMB & Office of Management and Budget \\
PI & Principal Investigator \\
PM & Program Manager \\
RCP & Representative Concentration Pathway \\
SAR & Sirtual Machine \\
\hline &
\end{tabular}




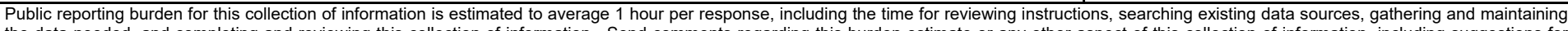

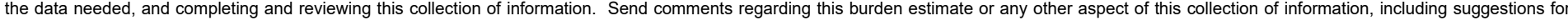

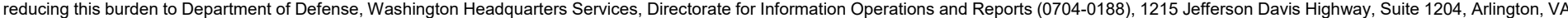

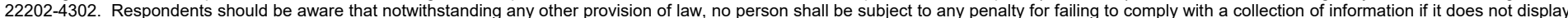
a currently valid OMB control number. PLEASE DO NOT RETURN YOUR FORM TO THE ABOVE ADDRESS.

\section{REPORT DATE (DD-MM-YYYY) July 2019}

4. TITLE AND SUBTITLE

Frequency of Extreme Weather Events Model User's Guide
3. DATES COVERED (From - To)

5a. CONTRACT NUMBER

5b. GRANT NUMBER

5c. PROGRAM ELEMENT NUMBER

5d. PROJECT NUMBER

402188

Byron M. Garton

5e. TASK NUMBER

5f. WORK UNIT NUMBER

8. PERFORMING ORGANIZATION REPORT NUMBER

ERDC/ITL SR-19-6

Information Technology Laboratory

U.S. Army Engineer Research and Development Center

3909 Halls Ferry Road

Vicksburg, MS 39180-6199

9. SPONSORING / MONITORING AGENCY NAME(S) AND ADDRESS(ES)

10. SPONSOR/MONITOR'S ACRONYM(S)

Headquarters, U.S. Army Corps of Engineers

Washington, DC 20314-1000

11. SPONSOR/MONITOR'S REPORT NUMBER(S)

\section{DISTRIBUTION / AVAILABILITY STATEMENT}

Approved for public release; distribution is unlimited.

\section{SUPPLEMENTARY NOTES}

\section{ABSTRACT}

Extreme weather events such as droughts and extended periods of high temperatures can have a negative impact on future force readiness and effectiveness. This model attempts to predict the likelihood of extreme weather events by calculating probabilities for several scenarios from future climate projections for various Department of Defense (DoD) installations.

This document describes the process of executing the Frequency of Extreme Weather Events Model, as it exists at the time of this writing, within the common computational environment established under the software integration effort of the Integrated Climate Assessment for Army Enterprise Planning work package.

\begin{tabular}{|ll}
\hline 15. SUBJECT TERMS & Long-range weather forecasting \\
& Drought forecasting \\
& Heat waves (Meteorology) \\
& Climatic changes--Risk assessment
\end{tabular}

\section{SECURITY CLASSIFICATION OF:}

a. REPORT

Unclassified

b. ABSTRACT
Unclassified

\section{c. THIS PAGE}

Unclassified
17. LIMITATION OF ABSTRACT

\section{NUMBER OF PAGES}

22 19a. NAME OF RESPONSIBLE PERSON

19b. TELEPHONE NUMBER (include area code) 